\title{
Classification of Croatian winegrowing regions based on bioclimatic indices
}

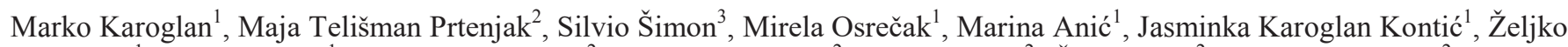
Andabaka $^{1}$, Ivana Tomaz ${ }^{1}$, Branko Grisogono ${ }^{2}$, Andreina Belušić2 ${ }^{2}$, Antun Marki ${ }^{2}$, Željka Prša ${ }^{2}$, Branimir Omazić ${ }^{2}$, Damjan Jelić $^{2}$, Željko Večenaj ${ }^{2}$, Višnjica Vučetić ${ }^{4}$, Damir Počakal ${ }^{4}$, Ivana Vladimira Petric ${ }^{3}$, Renata Leder ${ }^{3}$, Ivan Prša ${ }^{3}$.

${ }^{1}$ Faculty of Agriculture, Department of Viticulture and Enology, University of Zagreb, Zagreb, Croatia

${ }^{2}$ Department of Geophysics, Faculty of Science, University of Zagreb, Zagreb, Croatia

${ }^{3}$ Centre for Agriculture, Food and Rural Affairs of Croatia, Zagreb, Zagreb, Croatia

${ }^{4}$ Meteorological and Hydrological Service of Croatia, Zagreb, Croatia

\begin{abstract}
The aim of this work was to classifie vine growing regions of Croatia using bioclimatic indices. For the analysis of climatic conditions, linear trends of bioclimatic indices were determined using meteorological observations for all avaliable climatological stations located in vine growing regions of Croatia. Analysis were performed for two different climatological periods: 1961-1990 and 1988-2017. Four commonly used bioclimatic indices were determined: the Winkler index, the Huglin index, Cool night index and Growing season average temperature.
\end{abstract}

Key words: grapevine, bioclimatic indices, vineyard zoning, Croatia

\section{Introduction}

Viticulture and enology are important agricultural practices and one of the key economic activities in Croatia. Climate is the critical component of terroir limiting grape and wine production, which also determine suitability of particular grapevine (Vitis vinifera L.) varieties for wine production in the particular winegrowing region (Gladstones, 1992). Several bioclimatic indices are commonly used in vineyard zoning and in aim to describe suitability of climate of different winegrowing regions (Jones et al. 2010). Bioclimatic indices are also useful metrics to provide the information about climate changes impact on viticulture (Malheiro et al., 2010). One of the most widely used indices was temperature based Winkler index (WI), using a growing degree base of $10^{\circ} \mathrm{C}$ (growing degree-days; GDD), to place viticulture in the context of climate suitability (Amerine and Winkler, 1944). Correlating the WI with quality of grapes and wines production, they came up with five viticulture regions (Winkler et al, 1974). Despite the fact that their system has been changed among the years, WI still represent one of the most relevant bioclimatic indices. Jones (2006) defined five climate maturity groupings, ranging from very cool to very hot, based upon the average growing season temperature (TGS) and ability to ripen a given variety. The Cool Night Index (CI) which acounts for minimum temperatures during grapevine maturation period is also one of the strictly thermal indices (Tonietto 1999, Tonietto \& Carbonneau 2004). Using a degree-day approach, with the inclusion of a day-lenght factor as a proxy for radiation, the Huglin Heliothermal Index (HI; Huglin, 1978) allows assessing the thermal potential of a given region. HI can help in determination of the thermal demands for the ripening of each grape variety, also reflecting the potential grape sugar content.
The viticultural zoning in Croatia has been established in 1978, and was based on the several factors including climate, soils and topography of Croatian vineyards. In the mean time, we have witnessed that the Earth's average surface temperature has increased by approximately $0,7^{\circ} \mathrm{C}$ since the beggining of the century. Along with that, climate models forecast that the average global temperature will continue to rise (Branković et al., 2010).

The main goal of this study was to examine the curent spatial climate structure of the Croatian viticultural regions, using four standard grape-based bioclimatic indices, such as WI, TGS, CI and HI which were calculated for two different climatological periods.

\section{Material and methods}

Temperatures observation data for 29 meteorological stations located in Croatian viticultural regions were collected for the reference time period (1961-1990) for the present climate according to the World Meteorological Organisation. Beside that, the same observations were collected for the period of last 30 years (1988-2017), in aim to compare the data with the reference period. Data were provided by the Meteorological and Hydrological Service of Croatia. Bioclimatic indices were calculated as folows:

Growing degree-days (GDD or WI) according to Winkler et al. (1974):

$$
W I=\Sigma((\max +T \min ) / 2)-10^{\circ} \mathrm{C}
$$

Tmax - maximum daily temperature

Tmin - minimum daily temperature

Huglin Index (HI) according to Huglin (1978): 


$$
\Sigma=\left(\left(\text { Tavg }-10^{\circ} \mathrm{C}\right)+\left(\operatorname{Tmax}-10^{\circ} \mathrm{C}\right)\right) / 2 * \mathrm{k}
$$

Tavg - average daily temperature

$\mathrm{k}$ - latitude, daylenght adjustment factor

Cool night index (CI) according to Tonietto(1999) and

Tonietto and Carbonneau (2004):

$$
\mathrm{CI}=1 / \mathrm{N} \Sigma \mathrm{T} \min
$$

$\mathrm{N}$ - number of days in the period
Average growing season temperature according to Jones (2006):

$$
1 / N \Sigma((T \max +T \min ) / 2)
$$

In order to calculate agro-climatic indices, the interpolation method (using neighboring stations data) will be compiled by strings at those times and for those data where data is missing.

The bioclimatic indices were evaluated on the basis of

\begin{tabular}{|c|c|c|c|}
\hline INDEX & PERIOD & \multicolumn{2}{|c|}{ CLASSES DEFINATION } \\
\hline \multirow{7}{*}{$\begin{array}{l}\text { Average growing season } \\
\text { temperature (TGS) } \\
\text { Jones (2006) }\end{array}$} & \multirow{7}{*}{ April - October } & Too cool & $<13^{\circ} \mathrm{C}$ \\
\hline & & Cool & $13-15^{\circ} \mathrm{C}$ \\
\hline & & Intermediate & $15-17^{\circ} \mathrm{C}$ \\
\hline & & Warm & $17-19^{\circ} \mathrm{C}$ \\
\hline & & Hot & $19-21^{\circ} \mathrm{C}$ \\
\hline & & Very hot & $21-24{ }^{\circ} \mathrm{C}$ \\
\hline & & Too hot & $>24^{\circ} \mathrm{C}$ \\
\hline \multirow{5}{*}{$\begin{array}{c}\text { Growing degree - days (GDD or } \\
\text { WI) } \\
\text { Winkler et al. (1974) }\end{array}$} & \multirow{5}{*}{ April - October } & Region I & $<1390$ \\
\hline & & Region II & $1391-1670$ \\
\hline & & Region III & $1671-1940$ \\
\hline & & Region IV & $1941-2220$ \\
\hline & & Region V & $>2220$ \\
\hline \multirow{6}{*}{$\begin{array}{l}\text { Huglin index (HI) } \\
\text { Huglin (1978) }\end{array}$} & \multirow{6}{*}{ April - September } & Very cool (HI-3) & $<1500$ \\
\hline & & Cool (HI-2) & $1500-1800$ \\
\hline & & Temperate (HI-1) & $1800-2100$ \\
\hline & & Temperate warm $(\mathrm{HI}+1)$ & $2100-2400$ \\
\hline & & Warm (HI+2) & $2400-2700$ \\
\hline & & Very warm (HI+3) & $>2700$ \\
\hline \multirow{4}{*}{$\begin{array}{l}\text { Cool night index (CI) Tonietto } \\
\text { (1999) }\end{array}$} & \multirow{4}{*}{ September } & Very cool nights $(\mathrm{CI}+2)$ & $<12{ }^{\circ} \mathrm{C}$ \\
\hline & & Cool nights $(\mathrm{CI}+1)$ & $12-14{ }^{\circ} \mathrm{C}$ \\
\hline & & Temperate nights (CI-1) & $14-18^{\circ} \mathrm{C}$ \\
\hline & & Warm nights (CI-2) & $>18^{\circ} \mathrm{C}$ \\
\hline
\end{tabular}
the class levels listed in Table 1.

Table 1. Bioclimatic indices, formulas and classes definition

\section{Results and discussion}

Bioclimatic indices were analyzed for two climatic periods and for each of 29 meteorological stations individually. Results obtained were grouped according to main Croatian viticulture regions and subregions. There were 9 meteorological stations in Western continental Croatia region, 4 were placed in Eastern continental Croatia region and 16 in the Coastal Croatia region.

The areas of Croatian vineyards, according to these four bioclimate indices, belong to different classifications, depending on the region and subregion (Table 2).
Regarding reference time period, both Western and Eastern continental Croatia regions, ranging from 1086,7 to 1480,9 GDD belong to Winkler Region I and II. The same is for the recent climatological period (1988-2017), but with obvious higher temperature values ranging from 1323,9 to 1652,5 GDD. Coastal Croatia region ranged from 1325,1 to 2289,1 GDD for the reference period, thus belonging to Winkler regions I to V. Regarding recent climatological period, values ranged from 1496,5 to 2483,5 GDD, which means that Coastal Croatia region belongs to Winkler region II to V. 
Both Western and Eastern continental Croatia regions belonged to intermediate climate based on TGS regarding reference period, ranging from 15,1 to $16,9^{\circ} \mathrm{C}$. Regarding the period from 1988-2017, values ranged from 16,2 to 17,7 meaning that some parts of Continental Croatia region fall into warm climate according to TGS. The Coastal Croatia region for the reference period belonged to warm and hot category according to TGS ranging from 17,5 to $20,7^{\circ} \mathrm{C}$. Only one (Pazin) meteorological station measured lower TGS values $\left(16,2^{\circ} \mathrm{C}\right)$. Regarding recent climatological period, TGS values ranged from 17,0 to $21,6^{\circ} \mathrm{C}$, thus placing Coastal Croatian region in warm, hot and very hot climate.

According to the Huglin index and for the reference period, both Western and Eastern continental Croatia regions belonged to cool (HI-2) and temperate (HI-1) climate, ranging from 1611,3 to 2050,6 . In the period from 1988 - 2017, Huglin index ranged from 1855,4 to 2230,0 , placing both Continental Croatia regions in temperate (HI-1) and temperate warm $(\mathrm{HI}+1)$ climate. Huglin index in the reference period for the Coastal Croatian region ranged from 1919,9 to 2453,1 thus placing the region in the range from temperate (HI-1) to warm (HI-2) climate. When compared to the recent climatological period, the temperate climate class is missing, since the Huglin index ranged from 2100,5 to 2660,5 placing Coastal Croatian region in temperate warm (HI-1) and warm (HI-2) climate.

Cool night index for both Western and Eastern Continental Croatia did not change in either climatological periods and the whole region retained very cool nights $(\mathrm{CI}+2)$ with the measured maximum of $11,6^{\circ} \mathrm{C}$. Regarding reference period Coastal Croatian region $\mathrm{CI}$ ranged from $9,8^{\circ} \mathrm{C}$ to $18,4^{\circ} \mathrm{C}$. In the recent period CI ranged from 10,2 to $19,0^{\circ} \mathrm{C}$. Only one meteorological station (Pazin) measured very cool nights $(\mathrm{CI}+2)$ in both climatological periods.

The more precision results are obtained regarding subregions within three main regions., regarding recent climatological period 1988-2017.

According to Winkler index, the coolest winegrowing subregion in Croatia is Pokuplje, ranging between Region I and II. Subregions Podunavlje, Slavonija, ZagorjeMeđimurje, Prigorje-Bilogora and heartland of Istra belong to Region II. Dalmatinska zagora fall into Region III. The coastal part of Istra belong to Region IV, while subregions Hrvatsko-Primorje and Dalmacija range between Region IV and V.

According TGS index, the coolest winegrowing subregion in Croatia is Zagorje-Međimurje, followed by Pokuplje and Prigorje-Bilogora. Subregions Podunavlje, Slavonija and Dalmatinska zagora belong to warm climate, followed by Istra subregion ranging from warm to hot climate. Subregion Hrvatsko Primorje belong to hot climate, while the subregion Dalmacija ranges from hot to very hot climate.
According to Huglin index, winegrowing subregion Zagorje-Međimurje belongs to temperate climate, followed by Prigorje-Bilogora and Pokuplje subregions, which range between temperate and temperate warm climate. Subregions Podunavlje and Slavonija clearly fall into temperate warm climate. Subregions Istra, Hrvatsko Primorje, Dalmatinska zagora and Dalmacija vary between temperate warm and warm climate, depending on the location of meteorological station.

According to Cool night index, winegrowing subregions Podunavlje, Slavonija, Zagorje-Međimurje, Prigorje-Bilogora, Pokuplje as well as the heartland of Istra, all have very cool nights. In the subregion Dalmatinska zagora, night temperatures vary from very cool to cool. The coastal part of Istra and subregion Hrvatsko primorje have temperate hights, while night temperaturs in Dalmacija vary from temperate to even warm.

Calculated indices for Croatia winegrowing regions was compared to those of the other worldwide known winegrowing regions, according to Jones (2009). Considering TGS, WI and HI, all Croatian subregions are much warmer than all German regions, as well as than Bourgogne and Champagne regions. Winegrowing subregions from the continental part of Croatia have very similar climatic characteristics to Bordeaux, Côte du Rhône Méridionales, Barolo, Vatellina Superiore, Vino Nobile di Montepulciano and Rioja. On the other hand, winegrowing subregions from the coastal part of Croatia have very comparable climatic characteristics to the European regions Chianti Classico, Jerez, La Mancha, Porto and Vinho Verde, as well as to the Californian regions Napa Valley and Paso Robles.

Considering HI, there are certain limits regarding growing of different grape varieties. According to Huglin (1978), varieties such as Cinsault, Syrah, Grenache, Carignan, Mourverdre needs to be grown in temperate warm $(\mathrm{HI}+1)$ climate to reach maturity. Regarding this, such varieties are still not suitable for growing in Zagorje-Međimurje subregion as welll as in some parts of Pokuplje and Prigorje-Bilogora subregions.

There is a certain concerne regarding CI values for Dalmacija subregion. Warm nights very often have a negative impact on grape aroma, colour and acidity content. Night temperatures in other winegrowing regions of Croatia are favorable in the term of retaining satisfactory levels of organic acids, as well as aromatic and phenolic compounds.

\section{Consclusion}

This study provides detailed analysis of bioclimatic indices in Croatian winegrowing regions. Significant changes were noticed when comparing recent climatologic period (1988-2017) to the reference climatological period (1961-1990), thus pointing out the presence of climate changes in Croatia.

Bioclimatic indices values were compared to those from the other worldwide known winegrowing regions in 
order to evaluate viticulural potential in Croatia. But, for more precise comparison, more viticultural factors must be included (e.g. soils, precipitation etc.) since the same climatic group does not necessarily mean the same climate.
Further investigations are going toward phenology observations and grape quality measurements within single productive year.

However, this study provides accurate information needed for the questioning of existing and establishing a new viticulture zoning system in Croatia.

Table 2. Range values of bioclimatic indices of major Croatian winegrowing regions

\begin{tabular}{|c|c|c|c|c|c|c|c|c|c|}
\hline \multirow{2}{*}{ REGION } & \multirow[b]{2}{*}{ SUBREGION } & \multicolumn{2}{|c|}{ TGS } & \multicolumn{2}{|c|}{ GDD } & \multicolumn{2}{|c|}{ HI } & \multicolumn{2}{|c|}{ CI } \\
\hline & & $\begin{array}{l}1961- \\
1990\end{array}$ & $\begin{array}{l}1988- \\
2017\end{array}$ & $\begin{array}{l}1961- \\
1990 \\
\end{array}$ & $\begin{array}{l}1988- \\
2017\end{array}$ & $\begin{array}{l}1961- \\
1990 \\
\end{array}$ & $\begin{array}{c}\text { 1988- } \\
2017 \\
\end{array}$ & $\begin{array}{l}1961- \\
1990\end{array}$ & $\begin{array}{l}1988- \\
2017\end{array}$ \\
\hline \multirow{2}{*}{$\begin{array}{c}\text { EASTERN } \\
\text { CONTINENTAL } \\
\text { CROATIA }\end{array}$} & Podunavlje & $\begin{array}{c}16,2 \\
- \\
16,8 \\
\end{array}$ & $\begin{array}{c}17,3 \\
- \\
17,7 \\
\end{array}$ & $\begin{array}{c}1329,6 \\
- \\
1461,0 \\
\end{array}$ & $\begin{array}{c}1567,4 \\
- \\
1652,5 \\
\end{array}$ & $\begin{array}{c}1964,0 \\
- \\
2039,7 \\
\end{array}$ & $\begin{array}{c}2200,3 \\
- \\
2226,6 \\
\end{array}$ & $\begin{array}{c}9,8 \\
- \\
10,9 \\
\end{array}$ & $\begin{array}{c}10,5 \\
- \\
11,3 \\
\end{array}$ \\
\hline & Slavonija & 16,9 & 17,6 & 1480,9 & 1625,8 & 2050,6 & 2204,9 & 10,9 & 11,2 \\
\hline \multirow{3}{*}{$\begin{array}{c}\text { WESTERN } \\
\text { CONTINENTAL } \\
\text { CROATIA }\end{array}$} & $\begin{array}{l}\text { Zagorje - } \\
\text { Međimurje }\end{array}$ & 15,5 & 16,5 & 1184,8 & 1395,8 & 1776,3 & 1997,1 & 9,9 & 10,5 \\
\hline & $\begin{array}{l}\text { Prigorje - } \\
\text { Bilogora }\end{array}$ & $\begin{array}{c}15,4 \\
- \\
16,2 \\
\end{array}$ & $\begin{array}{c}16,6 \\
- \\
17,4 \\
\end{array}$ & $\begin{array}{c}1149,4 \\
- \\
1317,9\end{array}$ & $\begin{array}{c}1405,2 \\
- \\
1590,6\end{array}$ & $\begin{array}{c}1738,0 \\
- \\
1884,5\end{array}$ & $\begin{array}{c}1990,6 \\
- \\
2142,9\end{array}$ & $\begin{array}{c}9,3 \\
- \\
10,7 \\
\end{array}$ & $\begin{array}{c}10,1 \\
- \\
11,5\end{array}$ \\
\hline & Pokuplje & $\begin{array}{c}15,1 \\
- \\
16,8 \\
\end{array}$ & $\begin{array}{c}16,2 \\
- \\
17,4 \\
\end{array}$ & $\begin{array}{c}1086,7 \\
- \\
1449,2 \\
\end{array}$ & $\begin{array}{c}1323,9 \\
- \\
1574,7 \\
\end{array}$ & $\begin{array}{c}1611,3 \\
- \\
1979,9 \\
\end{array}$ & $\begin{array}{c}1855,4 \\
- \\
2142,7 \\
\end{array}$ & $\begin{array}{c}10,1 \\
- \\
11,4 \\
\end{array}$ & $\begin{array}{c}10,5 \\
- \\
11,2 \\
\end{array}$ \\
\hline \multirow{4}{*}{$\begin{array}{l}\text { COASTAL } \\
\text { CROATIA }\end{array}$} & Istra & $\begin{array}{c}16,2 \\
- \\
18,5 \\
\end{array}$ & $\begin{array}{c}17,0 \\
- \\
19,8 \\
\end{array}$ & $\begin{array}{c}1325,1 \\
- \\
1813,9 \\
\end{array}$ & $\begin{array}{c}1496,5 \\
- \\
2095,8 \\
\end{array}$ & $\begin{array}{c}1919,9 \\
- \\
2149,8 \\
\end{array}$ & $\begin{array}{c}2100,5 \\
- \\
2414,5 \\
\end{array}$ & $\begin{array}{c}9,8 \\
- \\
14,9 \\
\end{array}$ & $\begin{array}{c}10,2 \\
- \\
15,7 \\
\end{array}$ \\
\hline & $\begin{array}{l}\text { Hrvatsko } \\
\text { Primorje }\end{array}$ & $\begin{array}{c}18,4 \\
- \\
19,7\end{array}$ & $\begin{array}{c}19,5 \\
- \\
20,8\end{array}$ & $\begin{array}{c}1805,5 \\
- \\
2072,6\end{array}$ & $\begin{array}{c}2042,7 \\
- \\
2306,3 \\
\end{array}$ & $\begin{array}{c}2104,4 \\
- \\
2296,6\end{array}$ & $\begin{array}{c}2371,3 \\
- \\
2529,6\end{array}$ & $\begin{array}{c}15,0 \\
- \\
17,6 \\
\end{array}$ & $\begin{array}{c}15,0 \\
- \\
17,7\end{array}$ \\
\hline & $\begin{array}{c}\text { Dalmatinska } \\
\text { Zagora }\end{array}$ & $\begin{array}{c}17,5 \\
- \\
18,2\end{array}$ & $\begin{array}{c}18,2 \\
- \\
18,9 \\
\end{array}$ & $\begin{array}{c}1601,1 \\
- \\
1759,3\end{array}$ & $\begin{array}{c}1752,6 \\
- \\
1867,2 \\
\end{array}$ & $\begin{array}{c}2129,7 \\
- \\
2266,8\end{array}$ & $\begin{array}{c}2311,0 \\
- \\
2438,6\end{array}$ & $\begin{array}{c}11,4 \\
- \\
12,4 \\
\end{array}$ & $\begin{array}{c}11,4 \\
- \\
12,7 \\
\end{array}$ \\
\hline & Dalmacija & $\begin{array}{c}19,1 \\
- \\
20,7\end{array}$ & $\begin{array}{c}20,3 \\
- \\
21,6\end{array}$ & $\begin{array}{c}1948,4 \\
- \\
2289,1\end{array}$ & $\begin{array}{c}2193,9 \\
- \\
2483,5\end{array}$ & $\begin{array}{c}2221,3 \\
- \\
2476,0\end{array}$ & $\begin{array}{c}2433,5 \\
- \\
2660,5\end{array}$ & $\begin{array}{c}16,0 \\
- \\
18,0 \\
\end{array}$ & $\begin{array}{c}16,6 \\
- \\
18,2 \\
\end{array}$ \\
\hline
\end{tabular}

Series Number 9, Geological Association of Canada, St.

\section{Literature}

1. Amerine M.A., Winkler A.J. Composition and quality of musts and wines of California grapes. Hilgardia 15, 493-675 (1944)

2. Branković C̆., Srnec L., Patarčić M. An assessment of global and regional climate change based on the EH5OM climate model ensemble. Clim. Change. 98, 21-49. (2010).

3. Gladstones J. Viticulture and environment. WineTitles, Adelaide. 310 pp. (1992)

4. Huglin P. Nouveau Mode d'Evaluation des Possibilites Heliothermiques d'un Milieu Viticole. C. R. Acad. Agr. France, 1117-1126. (1978)

5. Jones G.V. Climate and Terroir: Impacts of Climate Variability and Change on Wine. In Fine Wine and Terroir- The Geoscience Perspective. Macqueen R.W., and Meinert L.D. (eds.), Geoscience Canada Reprint
John's, Newfoundland, 247 p (2006)

6. Jones G.V., Moriondo M., Bois B., Hall A., Duff A. Analysis of the Spatial Climate Structure in Viticulture Regions Worldwide. Proceedings of the 32nd World Congress of the Vine and Wine and 7th General Assembly of the International Organisation of Vine and Wine, June 28-July 3, 2009. Zagreb, Croatia (2009)

7. Malheiro A.C., Santos J.A., Fraga H., Pinto J.G. Climate change scenarios for viticultural zoning in Europe. Clim. Res. 43, 163-177. (2010).

8. Tonietto J. Les macroclimats viticoles mondiaux et l'influence du mesoclimat sur la typicite de la Syrah et du Muscat de Hambourg dans le sur de la France: 
methodologie de caracterisation. These Doctorat. Ecole Nationale Supericure Agronomique, Montpellier (1999)

9. Tonietto J., Carbonneau A. A multicriteria climatic classification system for grape-growing regions worldwide. Agric. Forest Meteorol. 124, 81-97. (2004).

10. Winkler A. J., Cook A., Kliewere W. M., Lider L. A. General Viticulture, (4th ed.), University of California
Press,
Berkeley,
740
p.
(1974). 